\title{
Palissy's philosophical pots
}

\section{The Huguenot Bernard Palissy is known for decorated grottoes and dishes. But he also helped to lead the way towards the use of empirical methods in science and the debunking of mystic medieval metaphysics.}

\section{Martin Kemp}

$\mathrm{N}$ owadays we think of the so-called 'applied' or 'decorative' arts as just that - combining functional application with decorative ornament — but not as conceptual vehicles for the kind of high seriousness that we associate with the 'fine arts' of painting and sculpture. But this is not a hierarchy that we can safely apply to art in the past. It is salutary to realise that a Hellenistic chalcedony dish in the Medici collection in Florence in 1492 was valued at 10,000 florins, while the most expensive painting (by Fra Angelico) rated only 100.

The famed ceramic dishes by the eccentric Huguenot potter, Bernard Palissy, now survive as curious items in collections of ceramics, but for the artist and his royal patrons in France his creations were of great visual and philosophical moment.

Palissy was named in 1563 as Inventeur des Rustiques Figulines du Roy ('King's Inventor of Rustic Ceramics') and gained renown as the maker of elaborate, semi-subterranean grottoes, including one in the area of the Louvre for Queen Caterina de' Medici. After the death of the widowed queen, he was finally imprisoned for his religious beliefs as a reforming Huguenot and met a melancholy end in the Bastille in 1590.

\section{What distinguished Palissy's work as a} grotto designer and potter was his extensive use of life casts of animals, brilliantly coloured with fused enamel glazes. Life casting of animals and plants became the expensive speciality of a number of goldsmiths in the sixteenth century, requiring prodigious skill, particularly for soft-bodied creatures.

Palissy virtually scooped the field in ceramics, having driven himself to exhaustion in mastering the huge technical problems of modelling and firing. His repertoire, most especially his marine creatures and amphibians, stands alongside the compelling images in the great contemporary picture books of natural history. But they are more than objects of supreme naturalism.

Palissy was the author of two extraordinary dialogues on the sciences of the Earth, published in 1563 and 1580. In the second of these, his Admirable Discourse on the Nature of Waters..., he exploits his artisan's stance as "a man without Latin" to debunk the elaborate metaphysics of the alchemists and abstruse philosophers. He advocates plain, straightforward explanations of age-

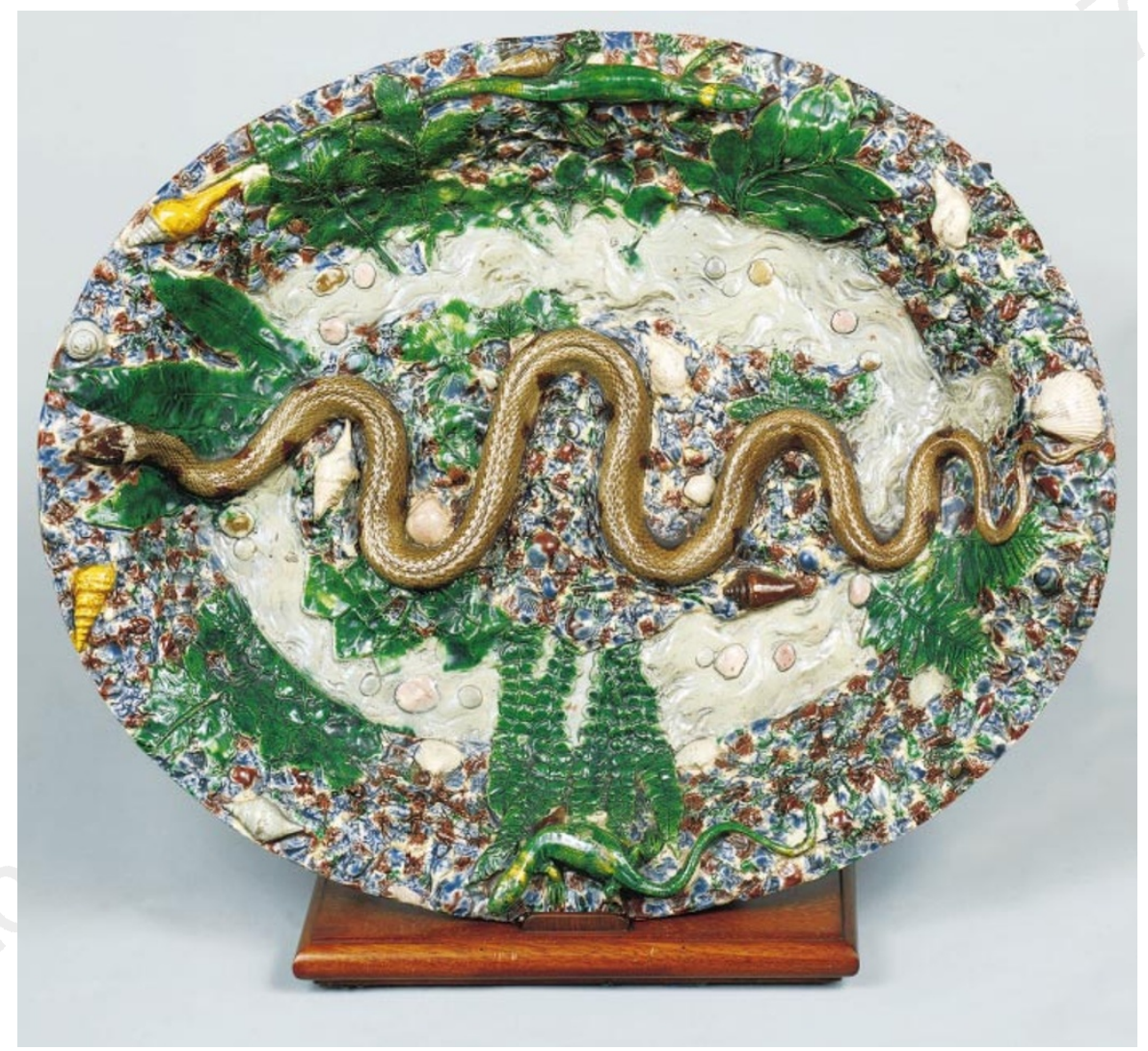

Bernard Palissy's Dish with Snake and other Life Casts.

old mysteries, such as the presence of springs on high mountains, and the formation of fossils.

Typically he attributes fossils to a casting process: "Just as all kinds of metals and other fusible materials take on the shape of the hollows or moulds in which they are placed or thrown, and even when thrown into the earth take the shape of the place where the material is thrown or poured, so the materials of all kinds of rocks take the shape of the place where the material has congealed."

Above all, he saw the fiery "womb of the Earth" mirrored in his own infernal kilns: "The kilns in which I bake my work have taught me much concerning the violence of fire; but among other things they have made me know the strength of the elements which generate earthquakes...."
Like a number of his aristocratic and learned contemporaries, he formed a 'cabinet of curiosities', but his was specifically designed to provide empirical proofs of his geological theories: "I have set up a cabinet in which I have placed many admirable and monstrous things which I have drawn from the womb of the Earth, and which give evidence of what I say, and no one will be found who will not be forced to admit them to be true."

Palissy stands as a supreme representative of the way in which the intrusion of practical knowledge and empirical methods into the philosophical mainstream did so much to fire the revolutionary changes in science around 1600.

Martin Kemp is in the Department of the History of Art, University of Oxford, 35 Beaumont Street, Oxford OX1 2PG, UK. 